Article

\title{
Associations between the Mixture of Governance Modes and the Performance of Local Public Service Delivery
}

\author{
Yin Lei Win Swe ${ }^{1}$ and Seunghoo Lim $^{2, *}$ \\ ${ }^{1}$ Department of Applied Economics, Yangon University of Economics, 11041 Yangon, Myanmar; \\ E-Mail: yinleiwinswe@gmail.com \\ 2 Public Management and Policy Analysis Program, Graduate School of International Relations, International University of \\ Japan, 9497277 Minami Uonuma, Japan; E-Mail: seunghoo.lim@gmail.com \\ * Corresponding author
}

Submitted: 8 May 2019 | Accepted: 27 September 2019 | Published: 25 November 2019

\begin{abstract}
Since the Myanmar central government decentralized some of its power to state and regional governments, few studies investigated the performance of local governments, and no studies investigated the relationships between the types of governance modes and the performance of public service delivery. This study investigates the associations between three types of governance-i.e., hierarchy, market, and network-and the multiple performances of agricultural services in terms of the competing public values of efficiency, effectiveness and equity in southern Shan State. The findings indicate that the three types of governance simultaneously coexist in local agriculture departments and that their associations with the performances of public services differ. Network governance is negatively associated with efficiency, effectiveness, and equity during its initial stage, but these associations become positive when the degree of network governance increases in agriculture departments. In contrast, market governance is positively related to effectiveness and equity during its initial stage; however, increasing the degree of market governance further leads to a negative association with both public service values. This assessment of the performance of public programmes in terms of the trade-offs among public service values contributes to improving the local governance of public service delivery not only in Myanmar but also in other developing countries.
\end{abstract}

\section{Keywords}

agricultural services; governance modes; Myanmar; network governance; policy tools; public service

\section{Issue}

This article is part of the issue "Trade-Offs in the Political Realm: How Important Are Trade-Offs in Politics?" edited by Todd Landman (University of Nottingham, UK) and Hans-Joachim Lauth (University of Wuerzburg, Germany).

(C) 2019 by the authors; licensee Cogitatio (Lisbon, Portugal). This article is licensed under a Creative Commons Attribution 4.0 International License (CC BY).

\section{Introduction}

In the economic, political and social sectors in Myanmar, decentralization has been one of the major reforms in the country's administration system since 2011, when the civilian government came to power. The union government has decentralized and delegated some powers to state and regional governments according to the 2008 Constitution. However, in Myanmar, state and regional governments have very limited power relative to the union government because of the short time required to reform. Although local-level governments have a low level of decentralization in Myanmar, their roles become prominent in delivering public services such as health, education, communication, and water supply. Because of the geography, insurgency, and insufficient skill and capability of government staff, public services still lag far behind a satisfactory level for local residents in some remote areas.

Among the various public services, this study examines the agricultural service provided by the local agri- 
culture department in Myanmar. The agriculture sector is the backbone of the country's economy, with $70 \%$ of the country's population living in rural areas and most of this group working as farmers (Nyein, 2009). Because of the high labour intensity combined with the low utilization of capital and material input in agricultural production and the undersupply of public goods such as agricultural research and extension, agricultural productivity in Myanmar is lower than in other neighbouring countries, and most of the country's rural farmers are poor (World Bank, 2016). There are still weaknesses in the collaboration between R\&D and extension and training institutions, including insufficiency in agriculture credits, underdevelopment of farm mechanization and utilization of farm implements due to the lack of improvement in technology, limited extension budgets and low salaries and incentives for public employees in the agriculture sector (Tin Wai, 2012). The public system cannot provide enough good seeds in Myanmar, while farmers in other Asian countries such as Thailand and Vietnam do not have difficulties with seed availability (World Bank, 2016). Moreover, farmers widely use urea and fertilizers without knowing the appropriate application rate and nutrient composition, and Myanmar farmers' level of fertilizer use is higher than that of farmers in other Asian countries (World Bank, 2016). Therefore, education and training services for farmers are critical and indispensable for enhancing their living standards, and the quality of services provided by the agriculture department requires assessment.

In this study, public service delivery by the local government in the agriculture sector will be examined in 21 townships in southern Shan State. Agriculture plays a crucial role in the economy of Shan State, and farming is the major income source for local residents. Poor knowledge of fertilizer usage and plantation, the accessibility of agricultural loans and grants, and a shortage of workers are major issues for farmers. Growing opium poppy in the hills of southern Shan State is another problem that must be efficiently approached by educating farmers (Department of Agriculture, 2017). Therefore, agricultural education and training services are very important to enhance farmers' knowledge, income, living standards, and agricultural productivity and to eradicate poppy planting. Most of the farmers in this area do not have a formal education or a good understanding of the Myanmar language. Additionally, there are some political instabilities and insurgencies in some townships.

The main functions of the agriculture department include: (i) seed production; (ii) training and education; (iii) research and development; and (iv) human resource development. In Myanmar, agriculture extension attempts to transfer appropriate agricultural technologies to farmers and determine solutions based on research investigating the field problems faced by farmers. The extension delivery methods used in the study area include: (a) Conducting workshops and training for capacity building to improve agricultural techniques, the systematic use of pesticides, fertilizers, and farm implements; (b) launching a special high yielding production programme (the SHY programme) in selected areas for selected crops; (c) establishing efficient contacts between farmers and extension agents through agricultural education camps (farmer field schools) and seasonal demonstrations; and (d) implementing training and visiting systems on farmers' fields (Department of Agriculture, 2017; Zaw Win Tun, personal communication, July 20, 2017).

Public management theories have discussed three types of governance-i.e., hierarchy, market, and network-as ways of solving complex societal problems and providing public services (Yoo \& Kim, 2012). These three types of governance coexist in a combined form in each governmental organization, and each service applies a mixture of these three governance modes in various contexts and countries (Keast, Mandell, \& Brown, 2006; Meuleman, 2008). However, our knowledge of the connections between these governance modes and their service delivery performances is quite limited. Coelho (2007) found that the effects of different governance modes on the efficiency of the education, health, and social protection systems differ in the Organisation for Economic Co-operation and Development countries, but this study did not sufficiently address the expanded multiple dimensions of performances in the public sector. For example, some previous studies have already employed the $3 E$ framework (i.e., "E"fficiency, "E"ffectiveness, and "E"quity) to assess the performance of public programmes in terms of competing public service values (Andrews \& van de Walle, 2013; Guo, Fu, Chui, \& Xue, 2017; Oh, Park, \& Lim, 2014).

The comprehensive study of the relationships between governance modes and performances in the Myanmar context is timely and urgent as the Myanmar public sector has recently experienced a rapid transition from a hierarchical and militarized regime to a more civilian and democratic regime. Some governance research in Myanmar has focused only on the trend of decentralization, the constitutional framework of local governance, and the government-military relationship in Myanmar (Lai Win \& Sripokangkul, 2017; The Asia Foundation, 2013; United Nations Development Programme [UNDP], 2015a, 2015b, 2015c). Thus, an empirical examination of the relationship between distinct but mixed governance modes and the results of public service delivery in Myanmar could provide relevant information regarding whether these changes could be legitimized from ordinary citizens' efficacies with these changes. The purpose of this study is to investigate the governance structure of public organizations for agricultural public services in Myanmar and the associations of the types of governance with the performances of public service delivery. Accordingly, this research is expected to contribute to improving the system of public service delivery and to furthering studies on the service delivery of local governance in Myanmar. 


\section{Modes of Governance}

Many prior studies on governmental roles have examined organizational and management patterns to explore ways of addressing societal or policy problems and accomplishing public goals. Prior studies have developed and tested three distinctive types of governance modesi.e., hierarchy, market, and network-and have also examined the relationships among them and how they both engage in trade-offs and coexist. As each mode of governance revolves around the distinct type of relationship (i.e., authoritative integration and supervisory structures given the hierarchical mode of governance, contractual relationships under the market mode of governance, and interdependent relationships based on trust with the network mode of governance), they could be incompatible with one another (Lowndes \& Skelcher, 1998; Maurya \& Srivastava, in press; Powell, 1991; Williamson, 1985). On the other hand, in terms of problem-solving capacity, they could be complementary to each other; for example, the emergence of market governance was related to the ineffectiveness of hierarchy governance (i.e., government failure), and it has been suggested that network governance addresses the societal problems of both market and government failures (Meuleman, 2008; Rhodes, 1997; Sørensen \& Torfing, 2007). Therefore, these three types of governance do not stand individually, and no service uses a singular governance mode (Yoo \& Kim, 2012).

\subsection{Hierarchical Governance}

Hierarchical governance is a type of public administration system that is ideal for standardizing governmental tasks (Meuleman, 2008). Weberian bureaucracy is based on the ideas of efficiency and rationality and is one of the fundamental factors in the development of bureaucratic organizations (Meuleman, 2008). Hierarchical governance standardizes rules and procedures to follow, a top-down planning system, power at the top, and a hierarchical supervision system, and it relies heavily on supervisors. The goal of individual employees in a hierarchical structure is to follow the right procedures to provide identical public services to clients, and public employees are controlled by centralized rules to give fair and equal services to the public (Considine \& Lewis, 1999; Yoo \& Kim, 2012). Due to the carefully and clearly defined procedures, tasks can be established uniformly within the organization. To obtain the desired outcomes, tasks can be divided into sub-processes depending on task specialization, rationality and the structure of the organization (Bednar \& Henstra, 2018; Mitchell, 1991). When individuals face societal problems, and cannot tackle the issues, they need to report to their superiors according to the hierarchical modes of supervision; there is close supervision, and supervisors know a considerable amount about their subordinates' daily activities. Therefore, hierarchical modes lead to systematic and obedient organization with uniform results.
However, some scholars criticized the hierarchical type of governance. Hierarchical governance lost some of its popularity in the mid-1970s, even if other types of governance were not yet clearly defined (Considine \& Lewis, 2003). In a hierarchically structured organization, power is at the top; scholars have criticized this type of organization for being a monocentric system and pointed out the need for a polycentric system to address more complex, wicked societal problems in public administration (Meuleman, 2008). Interdependent decisionmaking and coordination within and outside of the organization were considered necessary factors, and organizational goals were believed to be achieved by cooperating with other partners. Herbst (1976) stated that the assumptions of hierarchical governance did not suit a complex environment anymore. In particular, under the New Public Management (NPM) concept in the 1980s, policy makers adopted the idea that decentralization plays a key role in improving the efficiency of organizations, and market-type governance became popular.

\subsection{Market Governance}

Market governance functions like an external market within an organization, and it involves the establishment of a quasi- or internal market in the internal activities of a public organization (Considine \& Lewis, 1999; Thompson, Frances, Levacic, \& Mitchell, 1991).

Market governance was born in the 1980s based on the market logic and functions under the NPM concept. The main idea of NPM is to incorporate efficiency concepts, procedures and principles from the private sector into the public sector, and this idea was based on the belief that market logic and mechanisms lead to greater performance (Brown, Ryan, \& Parker, 2000; Considine, 1996; Considine \& Lewis, 1999). Market governance has fewer rules and regulations and greater managerial flexibility for public employees relative to hierarchical governance (Considine \& Lewis, 2003). Market logic replaced the strict rules and rigid system of hierarchical governance with a flexible management style, customer orientation and contractual basis for service delivery to reduce costs and offer multiple choices to customers through competition. Market governance became popular in the 1990s and has led governments to work with smart buyers when contracting out using competitive tenders to deliver public services to clients (Considine \& Lewis, 2003; Yoo \& Kim, 2012). Therefore, as a result of this type of governance, individual employees make flexible decisions depending on the different needs of clients when they are providing public services and goods.

Under NPM practices, constituents are considered customers of public programmes and services, and bureaucrats engage with citizens regarding public programmes and services for public interests to efficiently generate positive public recognition (Willoughby, 2014). In contrast with NPM in the ability to solve policy problems that can be addressed only through interdepen- 
dent policy decision-making, hierarchical governance lost some of its attractiveness (Meuleman, 2008). In many modern government bureaus, market-driven options, such as privatization and contracting out, are employed, and organizational operations are decentralized rather than operating through traditional hierarchical structures and command-and-control governance (Willoughby, 2014). Additionally, clients can choose among diverse services available due to the increased competition in public service delivery (Yoo \& Kim, 2012).

Market governance faced the criticism that, for many reasons, public organizations are different from private organizations and that business-like logic and practices sometimes fail in the public sector because citizens' roles extend beyond those of customers, and thus they cannot be viewed only as customers. In addition, the notion that public services are provided based on customer choices and satisfaction is questionable because the provision of public services is based on an adequate financial condition and budget allocation of public departments. The NPM concept of flexible management can conflict with some strict procedures and mandates in civil service and contribute to low morale in public administration, and privatization is also a short-term solution (Meuleman, 2008). The transition to a market-driven mode of governance tended to diminish the publicness of services in terms of eroding the public-private distinction, shrinking the socio-economic role, narrowing the composition of services recipients, worsening the conditions of accountability, and reducing the level of public trust (Haque, 2001).

\subsection{Network Governance}

Network governance is the management of complex societies through interdependent decisions among different actors. It has also been developed in Western public administration, with networking playing an important role in open democracy and the information technology revolution upgrading its importance in social life (Meuleman, 2008). Since the 1970s, many politicians and stakeholders have wanted different parties to participate in the public policy decision-making process. In addition, they preferred multi-actor policy making rather than a single controlling system. They expected that less control and more collaboration with other organizations could contribute to the effectiveness of public service delivery. Cooperation and interactions with various organizations to reach a common agreement among different views can contribute to the best solution for the public. It is believed that interdependent decision-making among different actors, the combination of different opinions, and less control and command may lead to improved effectiveness of public organizations (Denhardt \& Denhardt, 2000; Meuleman, 2008). Although hierarchical governance and market governance have been recognized as key modes, they cannot solve many issues associated with complex public programmes; thus, the importance of network governance must be considered (Keast et al., 2006). This type of governance provides horizontal coordination to improve organizational effectiveness, whereas market governance suggests decentralization and privatization (Bednar \& Henstra, 2018; Meuleman, 2008).

Network governance became a popular governance mode in the 1990s, as policymakers believed that it could solve more complex societal problems through collaboration and building trust among participants such as clients, suppliers, producers, and decision makers in a network (Considine \& Lewis, 2003; Ebrahimi \& Lim, 2018; Htein, Lim, \& Zaw, 2018; Vitiea \& Lim, 2019). A network makes better decisions for clients by increasing collaboration and interdependence with other organizations, and government rules are established to promote cooperative procedures among participants (Yoo \& Kim, 2012). The enterprise and network governance modes are currently operating as norms of public service delivery in addition to the older form of the hierarchical governance mode in modern societies (Considine \& Lewis, 2003).

\section{Multiple Dimensions of Public Service Performance in Terms of Public Values}

As mentioned above, to address complex public problems, it has become more important to utilize a mixture of the three governance modes and select optimal mixes (Keast et al., 2006). However, prior studies rarely discuss how a mixture of diverse governance modes could be matched to the outcomes, results, or situations of the competing modes desired by the citizens in a society. Although assessing the performance of the public sector is difficult, evaluating public sector performance in terms of competing norms and public values is important. Evaluation methods measure the actual quality and extent of public service delivery, the competency and management of public employees, and the extent of benefits that citizens receive. This type of policy or programme evaluation helps provide information on the functioning of actual programmes established and delivered, the management patterns of public administrators, and the performance of public service delivery (Guo et al., 2017). However, the three public service values of efficiency, effectiveness, and equity are completely different and there are trade-offs among them; a complete welfare scheme should have all three of these dimensions (Guo et al., 2017).

\subsection{Efficiency}

Efficiency can be achieved by producing the same amount of outputs with fewer inputs. The amount of expenditure, the size of the labour force, and the time used for a particular service represent the public service inputs. Efficiency relates to cost-saving and timesaving ways to achieve the desire output, and it does not focus on the quality of the output and its distribution. 
Therefore, efficiency could conflict with the other public service values of effectiveness and equity. Efficiency is related to the input-output relationship and productivity and is concerned with achieving maximum outcomes while minimizing costs (Guo et al., 2017). Efficiency can be achieved by reducing the amount of resources or inputs-i.e., time, money, and costs-used to produce the output. Technical efficiency depends on the extent to which the government reduces or saves costs when delivering public services. Contracting and privatization are approaches that public organizations have adopted to reduce costs (Oh et al., 2014). Although cost saving leads to efficiency, the quality of public services is not necessarily good, and the distribution of services is not necessarily equal (Oh et al., 2014).

\subsection{Effectiveness}

Effectiveness refers to the measurement of the achievement of the goals and objectives of public programmes (Oh et al., 2014). Effectiveness is an important value in the measurement of government performance because it is associated with the realization of the ultimate outcomes of public services. If a government organization emphasizes improved effectiveness, i.e., better quality of services, then effectiveness may not be associated with cost saving. Effectiveness is a criterion for assessing the achievement of desired results. Previous scholars have believed that efficiency could not be attained without effectiveness because achieving the desired goal is more important and because effectiveness is a necessary condition for achieving efficiency (Mihaiu, Opreana, \& Cristescu, 2010). Furthermore, effectiveness is more difficult to measure than efficiency because effectiveness involves assessing the achievement of the intended goals of programmes or policies, which may not be tangible or easily observable because public policies and programmes have both economic and social effects (Mihaiu et al., 2010).

\subsection{Equity}

Equity is the third public service value for the measurement of government performance regarding public services. Although equity is difficult to measure in the real world (Oh et al., 2014), the principle of equity is to measure the extent to which the allocation of services or distribution of outputs achieves fairness among the participants or service recipients. Equity is measured in terms of the extent to which public services are distributed fairly and equally among citizens, including disadvantaged groups. Equity refers to the degree to which a public organization can fulfil the requirements, demands, and needs of diverse citizens within a community (Andrews \& van de Walle, 2013). Equity is a criterion for measuring the degree of fairness in the allocation of resources and social benefits among a particular group of people (Guo et al., 2017). Therefore, the concept of eq- uity entails the availability of the same quality of public services between poor people and wealthy people.

\section{Research Method}

\subsection{Background of the Study Area}

Shan State is the largest state and has the greatest ethnic diversity among the fourteen regions and states of Myanmar. Its geography, topography, hilly and rugged terrain, and armed conflicts among ethnic groups have shaped the complicated socio-economic conditions of the inhabitants of Shan State for centuries (UNDP, 2015a, $2015 b, 2015 c)$. The remoteness of some areas suggest that this area still requires a well-functioning social infrastructure for transportation (lack of rural and urban roads), electricity (low levels of access to electricity), education (a shortage of qualified teachers), health (lack of trained personnel and medical equipment and the cost of medication), and agriculture sectors (poor knowledge regarding agriculture techniques), including educating farmers on poppy eradication and substitution because drug use and drug trade represent serious issues in Shan State (Centre for Diversity and National Harmony [CDNH], 2018; UNDP, 2015a, 2015b, 2015c). The cultivation of opium poppy is increasing because it requires a lower effort to obtain and provides a guaranteed return to farmers (CDNH, 2018). There is some relationship between the opium production economy and armed conflicts (Buchanan, 2016; Meehan, 2015).

Many various ethnic armed organizations (EAOs) have rebelled in Shan State since Myanmar gained independence in 1948. Although Shan State has the highest number of EAOs among other states, there are only two EAOs in Shan South, i.e., the Restoration Council of Shan State (RCSS) and Pa-Oh National Organization (PNO). PNO signed ceasefire since 1991 and has highly cooperated with the government in administering local populations through both the Pa-Oh Self-Administered Zone (SAZ) and its people's militia force. The PNO has become a political party and won all seats in Pa-Oh SAZ in the 2010 and 2015 elections. However, RCSS signed a ceasefire in 2011 and was permitted to have bases and locate in all rural areas. Although there have been many clashes between the RCSS and the Military over territorial disputes, such clashes declined in 2014 and 2015 in Shan South and Shan East (Burke, Williams, Barron, Jolliffe, \& Carr, 2017; Callahan \& Zaw Oo, 2019; Jolliffe, 2015).

This study covers only the delivery of agricultural services in southern Shan State in Myanmar. Three districts, i.e., Taunggyi, Loilen, and Langkho, are included in southern Shan State. Taunggyi district comprises 10 townships, Loilen district comprises seven townships, and Langkho district comprises four townships. There are two SAZs within Taunggyi district, i.e., Pa-Oh SAZ and Da-Nu SAZ (CDNH, 2018; Jolliffe, 2015). In total, 21 townships are included in this study; three townships are located in PaOh SAZ, and two townships are located in Da-Nu SAZ. 
PNO's administration over SAZ is nominal, and the governance structure and social services are almost the same as those in other government-controlled areas (Jolliffe, 2015). Because of the non-Da-Nu people purchase and take-over of some agricultural areas within the Da-Nu $S A Z$, the influence of the Da-Nu people is declining in their own SAZ (CDNH, 2018). Agriculture is the largest economic sector in Shan State, followed by the mining sector and tourism sector (CDNH, 2018). In this area, difficulties in accessing agricultural loans and grants, the shortage of workers in farming, poor knowledge of fertilizer and pesticide usages, and soil erosion are major issues for farmers (CDNH, 2018; Department of Agriculture, 2017). Furthermore, staff shortage leading to the inability to share information and knowledge with farmers, communication difficulties caused by differences in language, financial budget constraints, and political insurgencies and instability are major issues for the agriculture department (Department of Agriculture, 2017; Zaw Win Tun, personal communication, July 20, 2017).

Nationally, after five decades of authoritative military control, Myanmar has initiated a critical transition to an elected civilian government, and locally, Shan South is in the processes of armed-conflict reduction, but many national and local tensions are continuously challenging the tenuous political transformation. Therefore, currently, examining citizens' satisfactions and efficacies with these changes in governance modes and the outcomes pursued by local residents is urgently needed.

\subsection{Data Collection}

The necessary primary data were collected from local agriculture authorities and farmers through separate questionnaires. Overall, data from 275 farmers and 155 agricultural officers in 21 townships were collected in this study.

\subsection{Measurements}

\subsubsection{Dependent Variables}

The multiple performance values of public service delivery based on the $3 E$ framework that target a specific policy instrument (i.e., workshop training) are the dependent variables in this study. Policy instruments refer to tools utilized by policy makers to transform a policy into specific outcomes (Bemelmans-Videc, Rist, \& Vedung, 1998; Salamon, 2002).

In the study, survey data about the farmers' perceptions of the quality of the local agricultural service from the multiple competing public value perspectives of efficiency, effectiveness and equity were collected in the local research area through a questionnaire based on the following measurements adapted from Andrews and van de Walle (2013). In this study, efficiency is measured by the perceived value of the time the farmers spent receiving agricultural public services. Therefore, the farm- ers are asked whether the time spent attending the information sharing workshops was worthwhile. The efficiency of the public sector can be measured by the relationship between the economic and social benefits (output) resulting from the implemented programmes and the monetary and nonmonetary resources (input) used to implement those programmes (Mihaiu et al., 2010). Effectiveness is measured by whether the agricultural methods or techniques promulgated by the agriculture departments have been adopted by the farmers. The main objective of agricultural services is to promulgate systematic and modernized methods and educate farmers regarding these methods. Effectiveness is an indicator reflecting the achievement (outcome) of the implemented programmes (Mihaiu et al., 2010). To measure equity, farmers are asked whether they agree that educational/training services are distributed equally among all of the farmers living in the same township. Equity is measured by the extent to which public services are distributed fairly and equally among the citizens (Oh et al., 2014). To measure the three dependent variables, this study uses a dichotomous variable: If the farmers respond that the public services are efficient, effective, or equal, then that variable is coded as " 1 ," otherwise it is coded as "0" (see Annex, Table A1).

\subsubsection{Independent Variables}

The independent variables in this study are the three governance modes with their distinctive features. This study follows and adapts the methods to measure these variables developed by Yoo and Kim (2012). These authors adopted six characteristics-i.e., rules, discretion, supervision, clients, goals, and the environment-to measure the governance modes. These three main independent variables (hierarchy, market, and network) are measured by using 7-point Likert-type scales (see Annex, Table A1) ranging from strongly disagree $(=1)$ to strongly agree (=7).

\subsection{Estimation Method}

To examine the relationships between governance types and the three public service values, this article applied the Heckman selection model. Because some farmers have never attended the agricultural training workshop programmes conducted by agriculture departments, the relationships between governance types and the three public values should be examined only among farmers who received agricultural services, i.e., those who attended the training workshops. The Heckman selection model offers consistent and efficient estimates by providing a way to correct for sample selection bias (Heckman, 1979). It is a two-equation model that includes the outcome equation and the selection equation. The outcome equation for this study is as follows:

$y_{i}=\beta_{0}+\beta_{1} x_{1 i}+\beta_{2} x_{2 i}+\cdots+\beta_{n} x_{n i}+u_{i}$ and $u_{i} \sim N\left(0, \sigma_{u}^{2}\right)$ 
Where:

$y_{i}=$ Efficiency, effectiveness, and equity;

$x_{1 i}=$ Hierarchical governance;

$x_{2 i}=$ Market governance;

$x_{3 i}=$ Network governance;

$x_{4 i}=$ Age of the farmers;

$x_{5 i}=$ Years of education of the farmers;

$x_{6 i}=$ Occupation statuses of the farmers;

$x_{7 i}=$ Years of farming;

$x_{8 i}=$ Sizes of acres;

$x_{9 i}=$ Numbers of crops.

The outcome equation examines the relationships between governance types and public service values. Next, the selection equation is as follows:

$s_{i}=\delta_{0}+\delta_{1} z_{1 i}+\delta_{2} z_{2 i}+\cdots+\delta_{n} z_{n i}+e_{i}$ and $e_{i} \sim N(0,1)$,

Where:

$s_{i}=$ Farmers' workshop attendance (i.e., farmers attended the workshop if $s_{i}>0, s_{i}=1$ if $s_{i}>0$, and $s_{i}=0$ if $\left.s_{i} \leq 0\right)$;

$z_{1 i}=$ Gender;

$z_{2 i}=$ Age of the farmers;

$z_{3 i}=$ Years of education of the farmers;

$z_{4 i}=$ Majority ethnicity;

$z_{5 i}=$ Occupation statuses of the farmers;

$z_{6 i}=$ Years of farming;

$z_{7 i}=$ Sizes of acres;

$z_{8 i}=$ Numbers of crops.

The selection equation tests whether the farmers attended the educational/training workshops conducted by agriculture departments (Yes: 1 ; No: 0 ).

\section{Results}

This study applied the Heckman selection model to analyse the relationships between governance types and the three public service values regarding the policy instrument of workshop training. The three models are presented in Table 1: Model 1 regresses the independent and control variables on the efficiency measurement; Model 2 regresses the same variables on effectiveness; and Model 3 regresses on equity.

The results of Models 1 to 3 show that hierarchical governance is not significantly related to efficiency, effectiveness, or equity. Thus, in this study, the fixed rules and procedures, close supervision, and top-down operation structures of hierarchical governance cannot generate positive effects on the three performance values of public service delivery, implying that the local grievances expressed by Shan State farmers are a result of authoritarian, exclusionary, or hierarchical governance practices.

Market governance is not significantly related to efficiency in Model 1 but is significantly related to effectiveness in Model 2 and to equity in Model 3. Market governance is positively related to effectiveness (Model 2: $\beta=5.43, p<.01$ ) and equity (Model $3: \beta=5.33, p<.01$ ) in the initial stage market mechanisms used by agriculture departments, but is negatively related to effectiveness (Model 2: $\beta=-.24, p<.01$ ) and equity (Model 3: $\beta=-.24, p<.01$ ) when agriculture departments use market mechanisms to a greater extent. These results imply that using market governance tools and practices such as fostering competition among public employees and attempting to achieve the maximum returns initially generates positive outcomes; however, further implementation of market mechanisms can lead to negative outcomes in agricultural public service delivery.

In addition, the results of Models 1 through 3 indicate that network governance progresses at the expense of efficiency (Model 1: $\beta=-.52, p<.05$ ), effectiveness (Model 2: $\beta=-.71, p<.01$ ), and equity (Model 3: $\beta=-.51, p<.10)$ in its initial stage but is positively related to efficiency (Model 1: $\beta=.01, p<.05$ ), effectiveness (Model 2: $\beta=.02, p<.01$ ) and equity (Model 3: $\beta=.01, p<.10$ ) when there is a higher degree of network governance in agriculture departments. These results demonstrate that the higher the extent of network governance, the higher the efficiency, effectiveness, and equity of agriculture departments. These relationships imply that, to some degree, network governance requires trust to be built among the different actors to allow the government to make cooperative decisions with other organizations, and such trust, contacts, and interactions among different actors cannot be initiated, forged, or formed immediately.

In the selection equation, the number of years of education is positively associated with workshop attendance (Model 1: $\beta=.13, p<.01$; Model 2: $\beta=.12$, $p<.01$; Model 3: $\beta=.11, p<.01$ ). These results demonstrate that the higher the farmers' educational level, the more likely they are to attend the educational and training workshops conducted by agriculture departments. Belonging to an ethnic majority group (i.e., Shan) in the research site is also positively related to workshop attendance (Model 1: $\beta=.62, p<.05$; Model 2: $\beta=.54$, $p<.05$; Model 3: $\beta=.53, p<.05)$. These findings indicate that opportunities to attend workshops are offered to the ethnic majority group in this area more often than other ethnic minority groups. The diversity of crops cultivated by farmers is negatively related to workshop attendance (Model 1: $\beta=-.15, p<.05$; Model 2: $\beta=-.16$, $p<.05$; Model 3: $\beta=-.15, p<.05)$. Thus, the greater the number of crops planted by the farmers, the less likely they are to participate in workshops.

\section{Conclusion}

This study analysed the associations between the three types of governance and the efficiency, effectiveness, and equity of the agricultural services provided by local agriculture departments. The findings indicate that the local agriculture departments employed all three governance types-i.e., hierarchy, market, and network-to deliver agricultural services and that these three modes 
Table 1. Assessing the relationships between governance types and the three multiple public values for attendance at training workshops.

\begin{tabular}{|c|c|c|c|}
\hline & $\begin{array}{c}\text { Model } 1 \\
\text { (Efficiency) }\end{array}$ & $\begin{array}{c}\text { Model } 2 \\
\text { (Effectiveness) }\end{array}$ & $\begin{array}{l}\text { Model } 3 \\
\text { (Equity) }\end{array}$ \\
\hline \multicolumn{4}{|c|}{ Outcome Equation = Multiple Values of Public Service Delivery } \\
\hline Hierarchy & $-.38(1.65)$ & $1.60(2.44)$ & $3.91(3.39)$ \\
\hline Market & $.84(1.10)$ & $5.43(2.01) * * *$ & $5.33(1.99) * * *$ \\
\hline Network & $-.52(.22) * *$ & $-.71(.27) * * *$ & $-.51(.28)^{*}$ \\
\hline Hierarchy ${ }^{2}$ & $.008(.05)$ & $-.03(.07)$ & $-.09(.09)$ \\
\hline Market $^{2}$ & $-.032(.05)$ & $-.24(.09) * * *$ & $-.24(.09) * * *$ \\
\hline Network $^{2}$ & $.01(.01) * *$ & $.02(.01)^{* * *}$ & $.01(.01)^{*}$ \\
\hline Age & $-.006(.01)$ & $.02(.01)$ & $-.02(.02)$ \\
\hline Years of Education & $.04(.03)$ & $.03(.04)$ & $.004(.04)$ \\
\hline Occupation Status & $-.43(.50)$ & $.56(.64)$ & $.25(.59)$ \\
\hline Years of Farming & $.01(.01)$ & $-.01(.01)$ & $-.003(.02)$ \\
\hline Acres Cultivated & $-.03(.13)$ & $.06(.14)$ & $.16(.14)$ \\
\hline No. of crops & $.05(.06)$ & $.09(.07)$ & $.03(.07)$ \\
\hline \multicolumn{4}{|c|}{ Selection Equation $=$ Attending the Training Workshops or Not } \\
\hline Gender & $-.51(.35)$ & $-.36(.37)$ & $-.44(.35)$ \\
\hline Age & $.05(.07)$ & $.06(.07)$ & $.06(.05)$ \\
\hline Age $^{2}$ & $-.0002(.00)$ & $-.0003(.00)$ & $-.0004(.00)$ \\
\hline Years of Education & $.13(.04) * * *$ & $.12(.04) * * *$ & $.11(.03) * * *$ \\
\hline Majority Ethnicity & $.62(.26) * *$ & $.54(.26) * *$ & $.53(.26) * *$ \\
\hline Occupation Status & $.093(.72)$ & $-.11(.69)$ & $.03(.70)$ \\
\hline Years of Farming & $.062(.04)$ & $.05(.04)$ & $.05(.03)$ \\
\hline Years of Farming ${ }^{2}$ & $-.001(.00)$ & $-.001(.00)$ & $-.001(.00)$ \\
\hline Acres Cultivated & $.17(.18)$ & $.15(.17)$ & $.16(.17)$ \\
\hline No. of crops & $-.15(.07) * *$ & $-.16(.07)^{* *}$ & $-.15(.06)^{* *}$ \\
\hline Rho & .99 & .99 & 1.00 \\
\hline Wald Chi2 & 14.20 & 20.04 & 22.93 \\
\hline Selected & 237 & 237 & 237 \\
\hline Non-selected & 38 & 38 & 38 \\
\hline \multicolumn{4}{|l|}{ Wald test of rho $=0$} \\
\hline Chi2(1) & 6.81 & 3.67 & 3.36 \\
\hline Prob > Chi2 & .00 & .05 & .06 \\
\hline
\end{tabular}

Notes: ${ }^{*} \mathrm{p}<.10 ;{ }^{* *} \mathrm{p}<.05 ;{ }^{* * *} \mathrm{p}<.01$. Standard errors are in parentheses.

coexist in agriculture departments. Thus, these three types of governance developed sequentially and simultaneously affect governmental organizations (Keast et al., 2006; Yoo \& Kim, 2012). Extending beyond the consistent findings reported in previous public governance studies, we empirically and comprehensively showed the connections between the governance types and multiple results or outcomes of public services. All three types have their own virtues in delivering public services, and employing a combination of the three governance modes rather than relying on a single government mode is necessary for improving the performance and accountability of public services in a complementary way. Utilizing a single mode independently is not sufficiently effective to produce better public programmes, and a single mode cannot respond to the changing environment and complex societal demands.
Furthermore, our attention was paid to the dynamics between the mixture of governance modes and public service outcomes as previous studies have not answered the question of which governance mode and corresponding institutional arrangements could be optimal for which types of public values and interests in a society. This study demonstrated that mixed governance modes can differentially affect each public value depending on the evolutionary or developmental stages of each governance mode. First, market governance is positively associated with effectiveness and equity during the initial stage of the implementation of market mechanisms in agriculture departments; however, this relationship becomes negative after the optimal point, indicating that too strong a dependence on market practices and schemes within agriculture departments decreases effectiveness and equity. Thus, the increasing 
use of market behaviour in public organizations and the diminishing use of internal rules lead to a distortion and displacement of the organizations' original goals and objectives (Fox, 1974; Lane, 1991). Too much marketization could lead to a loss in the public interest concept and a collapse of the organizational structure of the public sector (Denhardt \& Denhardt, 2000).

In contrast, network governance is negatively related to efficiency, effectiveness, and equity during the initial stage of the implementation of network governance mechanisms, but this relationship becomes positive when network-oriented operations become more strongly incorporated in agriculture departments. At the initial implementation stage of network governance mechanisms, mutual trust, and collaborative behaviours among different actors are not strong enough to obtain positive results. Trust is essential for team building and group work but can be broken anytime as networks are open (Meuleman, 2008). However, after networking has reached the optimal degree, the mutual trust and collaborative relationships among the different participants have become strong, and the transaction costs are reduced; thus, the intended effects of network governance on performance values are achieved.

Local agriculture departments are currently coordinating with numerous organizations, including international non-governmental organizations, such as the Japan International Cooperation Agency, the UNDP, the United Nations Office on Drugs and Crime, and the Food and Agriculture Organization; private companies selling and distributing pesticides and fertilizers; other departments under the same ministry, such as the Irrigation and Water Utilization Management Department, the Department of Agriculture Land Management and Statistics, and the Myanmar Agriculture Development Bank; and other ministries, such as the Ministry of Environmental Conservation and Forestry. The participation of many different actors in public service delivery and the resultant coordination of different views for the production of better performance are key concepts in network governance. Public officials employing network governance can establish effective collaborations between suppliers, producers, and customers through a much more flexible way of developing the quality of service (Considine \& Lewis, 1999). The role of the government is not merely to direct all actions through rigid regulations and decrees; rather, it should bring other participants to the table to negotiate and facilitate solutions to public problems to improve community interests (Denhardt \& Denhardt, 2000). To achieve the community's shared goals, local agriculture departments should coordinate and cooperate with other organizations and invite the varied perspectives of farmers with empathy and trust. In the Myanmar civil service system, collaboration across administration bodies and shared decision making are still needed to upgrade performance (Htay Lwin, 2014).

Finally, hierarchical governance does not have any significant effect on any public service performance mea- sure. Myanmar public administration is still in a centralized nature of administration with the lack of sufficient impetus. The high and complicated bureaucratic procedures of most public departments should be solved, and giving incentives and motivation may lead to greater efficiency and effectiveness in civil services in Myanmar (Htay Lwin, 2014). Regarding market governance, the higher the degree of market behaviour, the lower the effectiveness, and equity of agricultural services. However, the higher the degree of implementation of network mechanisms, the higher the efficiency, effectiveness, and equity of agricultural services. The results show that market governance and network governance form a complementary pattern in the agricultural services in the study area. While the implementation of market mechanisms leads to a disintegration of the organizational structure of the public sector, network governance reintegrates this structure (Davis \& Rhodes, 2000).

The implication is that using only one governance mode in agriculture departments is inadequate to respond to the diverse demands of society. Each governance mode has its own advantages and disadvantages, and applying only one mode can cause problems (Keast et al., 2006). The weak points of hierarchical governance and market governance have led to networkbased ideas and concepts in public administration (Keast et al., 2006). Democracy, community, and the public interest should be considered, and public employees should pay attention to serving and empowering citizens rather than controlling and steering the community (Denhardt \& Denhardt, 2000). However, the best ideas of hierarchical governance and market governance should not be lost while adopting the new concepts of network governance.

Education, training, and the provision of resources such as agriculture loans, seeds, and fertilizers are capacity instruments among other policy tools (Schneider \& Ingram, 1990). The Department of Agriculture is currently providing high yielding variety of seeds and fertilizer to substitute opium poppy cultivation by organizing formal workshops in this study area (Department of Agriculture, 2017; Zaw Win Tun, personal communication, July 20, 2017). However, there is no significant improvement, and poppy production is still increasing in these areas (Meehan, 2015) mainly due to the large gap between the profit gained from normal seasonal crops and the profit gained from opium crops. Moreover, cultivating opium crops is largely related to ethnic armed conflict in these areas. The participation and empowerment of farmers are important for improving agricultural services. Oo and Ando (2012) noted that mass media should be used in agriculture extension to rapidly deliver uniform information to and properly inform farmers. Because of poor transportation, an inadequate number of instructors (extension staff), and a large number of farmers to reach, extension methods that use farm and home visits have encountered some problems. However, incentives for public employees are also needed to mo- 
tivate them to deliver services efficiently, effectively, and equitably. It is also necessary to improve the transparency in the payment system for hardship allowance and in-kind allowance in remote areas to motivate civil services (Japan International Cooperation Agency, 2017).

In addition, recruiting public employees who can understand and speak the regional language in the area studied is necessary because communication difficulties are a major issue affecting the efficient delivery of public services. The Burmese language is the common language of Myanmar, and all ethnicities have their own languages (Smith, 1994). In this study area, some local farmers use and understand only their own ethnic language, such as the Shan language, Pa-Oh language, etc., and they do not understand the Burmese language very well, especially in remote areas. However, some local farmers living near urban areas can speak and understand both the Burmese language and their own language, which is also related to their education level. The finding in the selection equation also shows that workshop attendance is positively related to the education level of the farmers.

Although there are two SAZs, i.e., Pa-Oh and Da-Nu, and one ceasefire EAO, i.e., RCSS, in this study area, this study could not consider "mixed administration" and its effect on public service delivery. If this factor was included in our analysis, it could produce more relevant information regarding public service delivery in Shan State. Despite this limitation, the distinct and differentiated effects of each governance mode on competing public values observed in this study should help all local governments that deliver public services not only in Myanmar but also in developing countries.

\section{Acknowledgments}

The authors wish to thank Mr. Khin Maung Yin, Mr. Cho Naing Tun, Mr. Zaw Win Tun, Mr. Sa Myint Thein, and other township managers and staffs from the Department of Agriculture in southern Shan State, Myanmar, for their support for conducting our surveys. We are also grateful to the editors and reviewers for their constructive comments and suggestions.

\section{Conflict of Interests}

The authors declare no conflict of interests.

\section{References}

Andrews, R., \& van de Walle, S. (2013). New public management and citizens' perceptions of local service efficiency, responsiveness, equity and effectiveness. Public Management Review, 15(5), 762-783.

Bednar, D., \& Henstra, D. (2018). Applying a typology of governance modes to climate change adaptation. Politics and Governance, 6(3), 147-158.

Bemelmans-Videc, M.-L., Rist, R., \& Vedung, E. (1998). Carrots, sticks, and sermons. London: Transaction
Publishers.

Brown, K., Ryan, N., \& Parker, R. (2000). New modes of service delivery in the public sector. International Journal of Public Sector Management, 13(2), 206-221.

Buchanan, J. (2016). Militias in Myanmar. Yangon: The Asia Foundation.

Burke, A., Williams, N., Barron, P., Jolliffe, K., \& Carr, T. (2017). The contested areas of Myanmar: Subnational conflict, aid, and development. Yangon: The Asia Foundation.

Callahan, M., \& Zaw Oo, M. (2019). Myanmar's 2020 elections and conflict dynamics. Washington, DC: United States Institute of Peace.

Centre for Diversity and National Harmony. (2018). Shan State needs assessment. Yangon: Embassy of Switzerland in Myanmar. Retrieved from https:// reliefweb.int/sites/reliefweb.int/files/resources/ Shan_State_Assessment_2018.pdf

Coelho, C. C. S. (2007). Modes of governance and public service efficiency (Unpublished Doctoral dissertation). University of Birmingham, Birmingham, England.

Considine, M. (1996). Market bureaucracy? Labour \& Industry, 7(1), 1-27.

Considine, M., \& Lewis, J. M. (1999). Governance at ground level. Public Administration Review, 59(6), 467-480.

Considine, M., \& Lewis, J. M. (2003). Bureaucracy, network, or enterprise? Public Administration Review, 63(2), 131-140.

Davis, G., \& Rhodes, R. A. W. (2000). From hierarchy to contracts and back again. In M. Keating, J. Wanna, \& P. Weller (Eds.), Institutions on the edge (pp. 74-98). Melbourne: Allen \& Unwin.

Denhardt, R. B., \& Denhardt, J. V. (2000). The new public service. Public Administration Review, 60(6), 549-559.

Department of Agriculture. (2017). Annual report of the district agriculture department. Taunggyi: Ministry of Agriculture, Livestock and Irrigation.

Ebrahimi, M. H., \& Lim, S. (2018). Network structures of interagency collaboration among counternarcotics stakeholders in Afghanistan. Romanian Journal of Political Science, 18(1), 8-42.

Fox, A. (1974). Beyond contract. London: Faber.

Guo, Y., Fu, Y., Chui, E. W. T., \& Xue, M. (2017). Equity, efficiency and effectiveness. Journal of Asian Public Policy, 10(2), 143-157.

Haque, M. S. (2001). The diminishing publicness of public service under the current mode of governance. Public Administration Review, 61(1), 65-81.

Heckman, J. (1979). Sample selection bias as a specification error. Econometrica, 47(1), 153-161.

Herbst, P. G. (1976). Alternatives to hierarchies. Leiden: Martinus Nijhoff.

Htay Lwin, H. (2014). Public administration and civil service system in Myanmar (Unpublished Doctoral dis- 
sertation). Yangon University of Economics, Yangon, Myanmar.

Htein, M. K., Lim, S., \& Zaw, T. N. (2018). The evolution of collaborative networks towards more polycentric disaster responses between the 2015 and 2016 Myanmar floods. International Journal of Disaster Risk Reduction, 31, 964-982.

Japan International Cooperation Agency. (2017). Data collection survey on civil service system in Myanmar: Final report. Naypyitaw: Union Civil Service Board.

Jolliffe, K. (2015). Ethnic armed conflict and territorial administration in Myanmar. Yangon: The Asia Foundation.

Keast, R. L., Mandell, M., \& Brown, K. A. (2006). Mixing state, market and network governance modes. International Journal of Organization Theory and Behavior, 9(1), 27-50.

Lai Win, M., \& Sripokangkul, S. (2017). Myanmar democratization path. Journal of MCU Peace Studies, 5(2), 335-347.

Lane, R. (1991). The market experience. Cambridge: Cambridge University Press.

Lowndes, V., \& Skelcher, C. (1998). The dynamics of multi-organizational partnerships. Public Administration, 76(2), 313-333.

Maurya, D., \& Srivastava, A. K. (in press). Relationship between governance mechanisms and contract performance. International Journal of Productivity and Performance Management. https://doi.org/ 10.1108/IJPPM-09-2018-0338

Meehan, P. (2015). Fortifying or fragmenting the state? The political economy of the opium/heroin trade in Shan State, Myanmar, 1988-2013. Critical Asian Studies, 47(2), 253-282.

Meuleman, L. (2008). Public management and the metagovernance of hierarchies, networks, and markets. Heidelberg: Physica-Verlag.

Mihaiu, D. M., Opreana, A., \& Cristescu, M. P. (2010). Efficiency, effectiveness and performance of the public sector. Romanian Journal of Economic Forecasting, 2010(4), 132-147.

Mitchell, J. (1991). Hierarchies. In G. Thompson, J. Frances, R. Levacic, \& J. Mitchell (Eds.), Markets, hierarchies \& networks (pp. 105-107). London: Sage.

Nyein, P. S. (2009). Agriculture productivity and diversification in Myanmar. In Myanmar Economic Management Institute (Ed.), Economic development in transition period of Myanmar (pp. 201-244). Yangon: Myanmar Book Centre.

Oh, Y., Park, J., \& Lim, S. (2014). Untangling the complexity of the association between contracting and local fiscal performance and income inequality in terms of competing values. Lex Localis, 12(4), 851-872.

Oo, K., \& Ando, K. (2012). Improving Myanmar agricultural extension services. Kyoto: Kyoto University.

Powell, W. (1991). Neither market nor hierarchy. In G. Thompson, J. Frances, R. Levacic, \& J. Mitchell (Eds.), Markets, hierarchies \& networks (pp. 265-276). London: Sage.

Rhodes, R. (1997). Understanding governance. Buckingham: Open University Press.

Salamon, L. M. (Ed.). (2002). The tools of government. New York, NY: Oxford University Press.

Schneider, A., \& Ingram, H. (1990). Behavioral assumptions of policy tools. Journal of Politics, 52(2), 510-529.

Smith, M. (1994). Ethnic groups in Burma: Development, democracy and human rights. London: Anti-Slavery International.

Sørensen, E., \& Torfing, J. (Eds.). (2007). Theories of democratic network governance. New York, NY: Palgrave Macmillan.

The Asia Foundation. (2013). State and region governments in Myanmar. Yangon: The Asia Foundation.

Thompson, G., Frances, J., Levacic, R., \& Mitchell, J. (1991). Markets, hierarchies \& networks. London: Sage.

Tin Wai, T. (2012). The role of institutions in agriculture sector development of Myanmar (Unpublished Doctoral dissertation). Yangon University of Economics, Yangon, Myanmar.

United Nation Development Program. (2015a). The state of local governance: Trends in Shan. Yangon: United Nations Development Programme.

United Nation Development Program. (2015b). The state of local governance: Trends in Myanmar. A synthesis of people's perspectives across all states and regions. Yangon: United Nations Development Programme.

United Nation Development Program. (2015c). Mapping the state of local governance in Myanmar. Yangon: United Nations Development Programme.

Vitiea, K., \& Lim, S. (2019). Voluntary environmental collaborations and corporate social responsibility in Siem Reap City, Cambodia. Sustainability Accounting, Management and Policy Journal, 10(3), 451-475.

Williamson, O. (1985). The economic institutions of capitalism. New York, NY: Free Press.

Willoughby, K. G. (2014). Public budgeting in context. San Francisco, CA: Jossey-Bass.

World Bank. (2016). Myanmar: Analysis of farm production economics. Washington, DC: The World Bank.

Yoo, J., \& Kim, S. (2012). Understanding the mixture of governance modes in Korean local governments. Public Administration, 90(3), 816-828. 


\section{About the Authors}

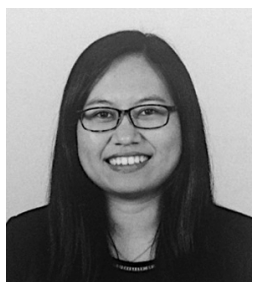

Yin Lei Win Swe is Assistant Lecturer in Economics in the Department of Applied Economics at the Yangon University of Economics, Myanmar. Her specializations are public policy process, macroeconomic policy, economic development, public administration, and public management.

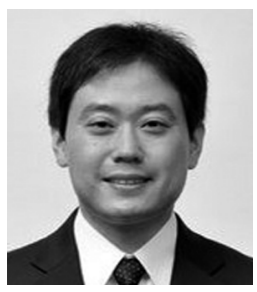

Seunghoo Lim is Professor of Public Policy at the International University of Japan, where he is the Director of the Public Management and Policy Analysis Program. His specializations are public policy process, network governance, policy tools, and public/nonprofit management. His research has appeared in refereed journals, including Journal of Public Administration Research \& Theory, Public Administration \& Development, Public Performance \& Management Review, International Review of Administrative Sciences, and Public Personnel Management, among others. 
Annex

Table A1. Measurements and sources of the variables.

\begin{tabular}{|c|c|c|}
\hline Variables & Measurements & Sources of Data \\
\hline \multicolumn{3}{|l|}{ Dependent variables } \\
\hline Efficiency & $\begin{array}{l}\text { Whether the time spent attending the information sharing } \\
\text { workshops conducted by the agriculture department was } \\
\text { worthwhile. (Yes: } 1 \text {; No: } 0 \text { ) }\end{array}$ & \multirow{3}{*}{$\begin{array}{l}\text { Service seekers } \\
\text { (farmers) } \\
\text { through survey } \\
\text { questionnaires }\end{array}$} \\
\hline Effectiveness & $\begin{array}{l}\text { Whether the methods promulgated by agriculture } \\
\text { department officers were adopted. (Yes: } 1 ; \text { No: 0) }\end{array}$ & \\
\hline Equity & $\begin{array}{l}\text { Whether the educational/training services were equally } \\
\text { available to all the farmers living in the same township. } \\
\text { (Yes: } 1 ; \text { No: } 0 \text { ) }\end{array}$ & \\
\hline \multicolumn{3}{|l|}{ Independent variables } \\
\hline Hierarchy & $\begin{array}{l}\text { Rules, discretion, supervision, clients, goals, and the } \\
\text { environment (7-point Likert-type scales) }\end{array}$ & \multirow{3}{*}{$\begin{array}{l}\text { Service providers } \\
\text { (agricultural } \\
\text { officers) through } \\
\text { the survey } \\
\text { questionnaires }\end{array}$} \\
\hline Market & $\begin{array}{l}\text { Rules, discretion, supervision, clients, goals, and the } \\
\text { environment (7-point Likert-type scales) }\end{array}$ & \\
\hline Network & $\begin{array}{l}\text { Rules, discretion, supervision, clients, goals, and the } \\
\text { environment (7-point Likert-type scales) }\end{array}$ & \\
\hline Farmers' years of experience & The number of years that the farmers have worked as farmers. & \multirow{9}{*}{$\begin{array}{l}\text { Service seekers } \\
\text { (farmers) } \\
\text { through survey } \\
\text { questionnaires }\end{array}$} \\
\hline Workshop attendance & $\begin{array}{l}\text { Attendance or non-attendance at workshops conducted by } \\
\text { the agriculture department. (Yes: } 1 \text {; No: } 0 \text { ) }\end{array}$ & \\
\hline Age & The age of the farmers & \\
\hline Gender & The gender of the farmers (Male: 1 ; Female: 0 ) & \\
\hline Education & The years of education completed/attended by the farmers & \\
\hline Ethnicity/race & $\begin{array}{l}\text { The ethnicity of the farmers } \\
\text { (Shan: 1; Non-Shan, including Pa-Oh, Bamar, Inn-Thar, } \\
\text { Da-Nu, Taung-Yo, Pa-Laung, Yinn, and others: 0) }\end{array}$ & \\
\hline Status of the farmers & Self-employed: 1 ; Tenants: 0 & \\
\hline Size of area cultivated & $\begin{array}{l}\text { How many acres do the respondents cultivate? } \\
\text { (1) None }(=0) \text {; ( } 2 \text { ) Below } 5 \text { acres }(=1) \text {; (3) 5-10 acres }(=2) \text {; } \\
\text { (4) } 11-20 \text { acres (= 3); (5) } 21-30 \text { acres }(=4) \text {; } \\
\text { (6) } 31-40 \text { acres (= 5); (7) } 41-50 \text { acres (= 6); (8) Above } 50 \text { acres }(=7)\end{array}$ & \\
\hline $\begin{array}{l}\text { Types of products } \\
\text { (number of crops) }\end{array}$ & $\begin{array}{l}\text { How many crops do the farmers cultivate? } \\
\text { (1) Rice; (2) Corn; (3) Potato; (4) Tomato; (5) Ginger; } \\
\text { (6) Garlic; (7) Soy bean; (8) Tea; (9) Coffee; (10) Vegetable; } \\
\text { (11) Flower; (12) Peas and beans; (13) Orchard crops } \\
\text { (crops grown in orchards) }\end{array}$ & \\
\hline
\end{tabular}


Table A2. Descriptive statistics.

\begin{tabular}{|c|c|c|c|c|c|}
\hline Variables & Obs. & Mean & S.D. & Minimum & Maximum \\
\hline Gender & 275 & .88 & $*$ & 0 & 1 \\
\hline Age & 275 & 41.87 & 11.89 & 14 & 80 \\
\hline Majority Ethnicity & 275 & .44 & $*$ & 0 & 1 \\
\hline Years of Education & 275 & 6.79 & 3.02 & 0 & 14 \\
\hline Occupation Status & 275 & .95 & $*$ & 0 & 1 \\
\hline Years of Farming & 275 & 21.04 & 12.60 & 1 & 60 \\
\hline Acres Cultivated & 275 & 1.43 & .76 & 0 & 7 \\
\hline No. of Crops & 275 & 3.53 & 1.66 & 1 & 10 \\
\hline Workshop Attendance & 275 & .86 & $*$ & 0 & 1 \\
\hline Efficiency & 275 & .19 & $*$ & 0 & 1 \\
\hline Effectiveness & 275 & .16 & $*$ & 0 & 1 \\
\hline Equity & 275 & .16 & $*$ & 0 & 1 \\
\hline Hierarchy & 275 & 17.92 & 1.30 & 15 & 21 \\
\hline Market & 275 & 11.57 & 1.50 & 8 & 14 \\
\hline Network & 275 & 18.41 & 3.49 & 11 & 23 \\
\hline
\end{tabular}

Notes: ${ }^{*}$ designates binary variable $(0,1)$. 